\title{
Aplikasi Bakteri Penambat N (BPN) dan Pupuk Kotoran Sapi (PKS) pada Fitoremediasi Tanah Tercemar Minyak Bumi
}

\begin{abstract}
Korespondensi: rizkiibnu083@gmail.com

Abstract. $N$-fixing bacteria (BNF) and cow manure (CM) were known to function as biostimulants on polluted soils by hydrocarbon compounds through rhizodegradation processes. This rhizodegradation mechanism can be helped by one of the hyperaccumulating plants of ramie. The study was aimed to identify how the best possible combinations of (BNF) and (CM) could improve polluted soils by using hemp plants (ramie). The experimental method used a randomized group-design, consisting four treatment combinations that are without the BNF + without the CM (control), azotobacter sp. + without the CM, without the BNF +CM 100\% dose and azotobacter sp. $4 \%+B N F 100 \%$ dose. The results showed that a combination of BNF and CM treatment had not significant difference to control, except a combination without the $B N F+$ dose $100 \%$ combination that could increase the population of azotobacter $s p$. $4.8 \times 108 \mathrm{cfu} / \mathrm{g}$, while azotobacter sp. + without the CM could increased the degradation of hydrocarbons and the dry weight of hemp plants $0.1047 \mathrm{ppm} /$ day and $40.433 \mathrm{~g}$.
\end{abstract}

\author{
Ibnu Rizki Perdana, Tualar Simarmata, Pujawati Suryatmana \\ Fakultas Pertanian, Universitas Padjadjaran, Jl. Raya Bandung-Sumedang Km. 21, Bandung, \\ Indonesia
}

Keywords: BNF, Cow Manure, Hydrocarbon, Phytoremediation, Ramie

\begin{abstract}
Abstrak. Bakteri Penambat N (BPN) dan Pupuk Kotoran Sapi (PKS) diketahui dapat berfungsi sebagai biostimulan pada tanah tercemar minyak bumi dengan merombak senyawa hidrokarbon melalui proses rhizodegradasi. Proses mekanisme rhizodegradasi ini dapat dibantu dengan salah satu tanaman hyperakumulator yaitu rami. Penelitian ini bertujuan untuk mengetahui perlakuan kombinasi terbaik antara (BPN) dan (PKS) yang dapat memperbaiki tanah tercemar minyak bumi dengan menggunakan tanaman rami. Metode percobaan yang digunakan adalah Rancangan Acak Kelompok (RAK), yang terdiri dari empat kombinasi perlakuan yaitu tanpa BPN + tanpa PKS (kontrol), Azotobacter sp. + tanpa PKS, tanpa BPN + PKS dosis $100 \%$ dan Azotobacter sp. $4 \%+$ PKS dosis 100\%. Hasil percobaan menunjukkan bahwa kombinasi perlakuan BPN dan PKS memberikan pengaruh yang tidak berbeda nyata terhadap kontrol, kecuali kombinasi tanpa BPN + PKS dosis $100 \%$ yang dapat meningkatkan populasi Azotobacter sp. 4.8 x 108 CFU / g, sedangkan Azotobacter sp. + tanpa PKS dapat meningkatkan degradasi hidrokarbon dan berat kering tanaman rami $0.1047 \mathrm{ppm} /$ hari dan $40.433 \mathrm{~g}$.
\end{abstract}

Kata Kunci : BPN, fitoremediasi, hidrokarbon, pupuk kotoran sapi rami.

\section{PENDAHULUAN}

Kebutuhan manusia akan energi minyak bumi mengalami peningkatan tiap tahunnya. Konsumsi dan produksi rata-rata minyak bumi di Indonesia pada bulan Juni tahun 2016 berturut-turut meningkat sebanyak 1.615 juta barel perhari dan 834.4 ribu barel perhari (Kementerian Energi dan Sumber Daya Mineral. 2016). Hal ini sejalan dengan bertambahnya kasus pencemaran tanah akibat tumpahan limbah minyak bumi di berbagai daerah Indonesia. Pencemaran tanah akibat aktivitas pabrik menyebabkan tanah seluas 2.2 Ha di PT. Unilever Jakarta dan 8 Ha di PT. Caltex telah terdegradasi minyak bumi, selain itu kebocoran pipa minyak di PT. Connoco Phillips sepanjang $300 \mathrm{~m}$ telah memberikan dampak 
terhadap lingkungan, dan banyak kasus pencemaran lain akibat tumpahan limbah minyak bumi di Indonesia (Walhi 2007).

Fitoremediasi merupakan metode pengolahan limbah secara biologis dengan meminimalkan volume, mobilitas, dan atau toksisitas di dalam tanah, air tanah, atau media lain yang terkontaminasi (USEPA 2002), dengan syarat konsentrasi maksimal limbah minyak bumi yang dapat difitoremediasi yaitu 15\% (Kepmen LH 2003). Tanaman rami diketahui sebagai tanaman hyperacumulator yang toleran pada lingkungan stress, seperti tanah tercemar logam berat dan hidrokarbon minyak bumi (Wei et al. 2015). Fitostimulasi atau rhizodegradasi merupakan salah satu mekanisme tanaman hyperacumulator dalam memperbaiki tanah terkontaminasi polutan yaitu dengan memproduksi eksudat akar berupa senyawa protein, asam-asam organik, atau senyawa lain yang diperlukan oleh aktivitas mikroba tanah untuk mendegradasi senyawa toksik hidrokarbon (Widyati 2009).

Kendala utama dari sifat tanah tercemar minyak bumi adalah kelarutan tanah yang rendah, konsentrasi polutan yang terlalu tinggi, serta kurangnya daya adaptabilitas tanaman terhadap kondisi lingkungan tercemar, sehingga menyebabkan hasil degradasi polutan menjadi kurang efektif (Allen et al. 1998). Faktor lain yang dapat menghambat terjadinya proses degradasi hidrokarbon antaralain, pengaruh oksigen, kelembaban tanah yang kurang optimal, suhu dan intensitas cahaya yang terlalu tinggi, ketersediaan nutrisi yang terlalu rendah, kondisi $\mathrm{pH}$ terlalu tinggi, maupun jumlah populasi mikroba yang sangat rendah pada tanah tersebut (Pratiwi et al. 2017). Salah satu ordo tanah yang memiliki luasan yang cukup besar dan memiliki sifat tanah yang berpotensi sulit dalam mendegradsi tumpahan minyak bumi secara alami adalah Inceptisols.

Inceptisols asal Jatinangor memiliki kandungan $\mathrm{N}$ total sebesar $0.15 \%$, jumlah ini belum dapat memenuhi kebutuhan nitrogen utama tanaman pada tanah tercemar minyak bumi (Fauzi 2017). Oleh karena itu dibutuhkan rekayasa yang dapat meningkatkan nutrisi dan kondisi perakaran yang baik pada tanah Inceptisols. Bakteri Penambat Nitrogen (BPN) merupakan agen hayati yang dapat menambat nitrogen bebas (N2) dari udara dan merubahnya menjadi amonia (NH3), yang dapat disintesis menjadi asam amino, sehingga bisa digunakan tanaman untuk tumbuh dan berkembang (Alexander 1977). Pupuk kotoran sapi diketahui sebagai salah satu jenis bahan organik yang dapat digunakan pada tanah tercemar minyak bumi karena bisa memperbaiki sifat fisik, kimia dan biologi tanah melalui perannya sebagai sumber nutrisi mikroba tanah (Sugito et al. 1995). Aplikasi BPN (Azospirillum sp. dan Azotobacter sp.)serta pupuk kotoran sapi diharapkan mampu meningkatkan populasi penambat $\mathrm{N}$, degradasi hidrokarbon dan pertumbuhan tanaman rami pada tanah tercemar minyak bumi.

\section{MATERI DAN METODE}

Penelitian ini dilaksanakan di Laboratorium Biologi Tanah, Laboratorium Kesuburan Tanah dan Nutrisi Tanaman, serta Rumah Kaca Kebun Percobaan Fakultas Pertanian Universitas Padjadjaran. Penelitian ini dilaksanakan dari bulan Januari 2019 hingga April 2019.

\section{Materi Penelitian}

Alat dan bahan yang digunakan dalam penelitian ini antara lain : laminar air flow, autoclave, incubator, mikroskop, tabung reaksi, erlenmeyer $250 \mathrm{ml}$, botol vial ukuran $25 \mathrm{ml}$ dan $100 \mathrm{ml}$, petridish, oven, polybag kapasitas $10 \mathrm{~kg}$, Inceptisols Jatinangor, crude oil yang berasal dari Pertamina Balongan Indramayu, tanaman rami klon Lembang, inokulan Bakteri Penambat N (BPN) (Azotobacter sp.) koleksi Laboratorium Biologi Tanah Fakultas Pertanian Universitas Padjadjaran, media Ashby's, pupuk kotoran sapi (PKS), pupuk anorganik (urea, SP-36, $\mathrm{KCl}$ ), dan bahan-bahan kimia untuk penghitungan Total Petroleum Hydrocarbon (TPH) (n-heksan, akuades, dan natrium sulfat).

\section{Metode Penelitian}

Penelitian ini dilakukan di rumah kaca menggunakan metode percobaan Rancangan Acak Kelompok (RAK) dengan kombinasi perlakuan sebagai berikut :

$\mathrm{a}_{0} \mathrm{~b}_{0}=$ tanpa BPN + tanpa PKS (kontrol)

$\mathrm{a}_{2} \mathrm{~b}_{0}=$ Azotobacter sp. + tanpa PKS

$\mathrm{a}_{0} \mathrm{~b}_{2}=$ tanpa BPN + PKS dosis $100 \%$ 
$\mathrm{a}_{2} \mathrm{~b}_{2}=$ Azotobacter sp. $4 \%+$ PKS dosis $100 \%$.

Dari empat kombinasi perlakuan tersebut diulang tiga kali, sehingga didapat total perlakuan sebanyak 12 satuan percobaan. Setiap unit percobaan terdiri dari satu tanaman/polybag, sehingga total tanaman yang dibutuhkan pada penelitian ini sebanyak 12 tanaman yang ditempatkan sesuai dengan tata letak percobaan RAK.

Media tanah yang digunakan untuk bahan penelitian ini merupakan Inceptisols asal Jatinangor dengan kebutuhan tanah total sekitar $5 \mathrm{~kg}$ x 36 unit $=180 \mathrm{~kg}$. Bahan organik berasal dari pengomposan kotoran sapi yang sudah matang di kandang Fakultas Peternakan Universitas Padjadjaran. Kebutuhan total pupuk kotoran sapi yang dibutuhkan dalam penelitian ini sebanyak $0.45 \mathrm{Kg}$.

Pengambilan contoh tanah dilakukan secara komposit pada lima titik sampel menggunakan cangkul dengan metode sampling diagonal di kedalaman $0-20 \mathrm{~cm}$ dari permukaan tanah. Tanah dibersihkan dari sisa tanaman dengan cara disaringdan dikering anginkan selama satu hari, kemudian dilakukan analisis sifat kimia tanah (pH, N-total, P-tersedia, dll) dan biologi tanah awal (populasi mikroba). Kebutuhan sampel tanah yang digunakan untuk analisis masing-masing $500 \mathrm{~g}$. Sampel pupuk kotoran sapi yang dianalisis merupakan hasil pengomposan yang dibutuhkan sebanyak $500 \mathrm{~g}$ untuk analisis kimia (Corganik, N-total, C/N, P, K) dan biologi yaitu populasi BPN.

Media pembibitan terdiri dari tanah dan kompos dengan perbandingan $1: 1$ (tanah dan kompos) yang dicampur menggunakan sekop pada wadah baki bervolume $50 \times 30 \times 25 \mathrm{~cm}$. Perbandingan 1:1 dipilih untuk pembibitan agar mengoptimalkan pertumbuhan akar tanaman, serta tidak merusak media perakaran ketika dilakukan pindah tanam di media polybag dengan berat tanah dan kompos masingmasing $1 \mathrm{Kg}$. Media yang sudah tercampur dimasukkan ke baki pembibitan sebanyak $3 / 4$ dari volume baki yang selanjutnya disiram dengan air hingga lembap. Rhizome tanaman rami yang digunakan dalam penelitian ini sudah dibibit selama 12 minggu (180 hari) pada media pembibitan dengan ukuran bibit rami sekitar $\pm 10 \mathrm{~cm}$.

Bioagen diperbanyak dengan metode refresh yaitu memperbanyak biakan murni mikroba menggunakan media miring selektif BPN yang dalam penelitian ini menggunakan bioagen dari jenis Azotobacter sp. dan Azospirillum sp. Media miring selektif Ashbys padat digunakan untuk perbanyakan Azotobacter sp., dan NFB (Nitrogen FreBromthymol Blue) digunakan untuk perbanyakan Azospirillum sp. Persiapan inokulan BPN dilakukan di dalam laminar flow dengan menuangkan $10 \mathrm{~mL}$ larutan $\mathrm{NaCl}$ $0.85 \%$ untuk melarutkan inokulan BPN hasil perbanyakan pada agar miring yang kemudian diinokulasikan ke dalam media selektif cair Azotobacter sp. (Ashbys) dan Azospirillum sp. (NFB). Kepadatan mikroba dihitung untuk mengetahui populasi terbaik yang akan digunakan pada aplikasi perlakuan.

Limbah minyak bumi seberat $378 \mathrm{~g}$ atau setara dengan 7\% dari TPH awal diencerkan dengan oli $2 \%$ yaitu $2 \mathrm{~mL}$, agar mudah dihomogenkan dengan media tanah. Total limbah minyak bumi yang dibutuhkan dalam penelitian ini sebanyak $378 \mathrm{~g}$ x 36 unit $=13.608 \mathrm{~g}$ sedangkan total oli yang dibutuhkan sebanyak $2 \mathrm{~mL}$ x 36 unit $=72 \mathrm{~mL}$. Tanah yang sudah terkontaminasi minyak bumi dimasukkan ke dalam polybag. Aplikasi pupuk kotoran sapi ditaburkan disekitar rhizosfer tanah yang sudah terkontaminasi minyak bumi sesuai perlakuan. Media tanam yang sudah diberi perlakuan diinkubasi selama seminggu agar $\mathrm{C} / \mathrm{N}$ pupuk kotoran sapi dapat turun sehingga mikroba dan tanaman dapat tetap eksis ketika ditanam pada tanah tercemar minyak bumi.

Aplikasi BPN Azotobacter sp. dari hasil perbanyakan yang diambil sebanyak 4\% (15.12 mL) menggunakan suntikan bervolume $50 \mathrm{~mL}$. Kebutuhan total inokulan BPN sebanyak $3 \times 9 \times 15.12 \mathrm{~mL}=$ $408.24 \mathrm{~mL}$. Isolat BPN diinokulasikan ke dalam media tanah dengan cara dituangkan disekitar rhizosfer tanah yang telah tercampur dengan pupuk kotoran sapi dan minyak bumi.

Penanaman tanaman rami dilakukan dengan melubangi media hingga kedalaman 5-7 $\mathrm{cm}$ dan jarak tanam sebesar 30 x $30 \mathrm{~cm}$ dari antar pangkal batang tanaman rami. Aplikasi pupuk anorganik dilakukan seminggu setelah tanam pada tiga lubang yang terpisah. Jenis pupuk anorganik yang digunakan adalah pupuk N, P, K, tunggal. Pemupukan pada percobaan ini dilakukan dengan aplikasi $1 / 2$ dosis anjuran dari Balai Penelitian Tanaman Tembakau dan Serat yaitu dengan pemberian pupuk Urea (46\% N) $120 \mathrm{~kg}$, 
pupuk SP-36 (36\% P2O5) $20 \mathrm{~kg}$, dan pupuk $\mathrm{KCl}(60 \% \mathrm{~K} 2 \mathrm{O}) 60 \mathrm{~kg}$ per hektar, sehingga kebutuhan pupuk per polybag menjadi $0.15 \mathrm{~g}$ Urea, $0.025 \mathrm{~g}$ SP-36, dan $0.075 \mathrm{~g} \mathrm{KCl}$. Berdasarkan angka tersebut maka total kebutuhan pupuk urea sebanyak $5.4 \mathrm{~g}$, SP-36 sebanyak $0.9 \mathrm{~g}$ dan $\mathrm{KCl} 2.7 \mathrm{~g}$.

\section{Laju degradasi hidrokarbon}

Laju degradasi hidrokarbon dianalisis dengan metode gravimetri menggunakan pelarut n-Heksan. Analsis TPH dilakukan selama dua bulan, pada tujuh titik pengamatan yaitu t0 (0 HSA), t1 (7 HSA),t2 (14 HSA), t3 (28 HSA), t4 (42 HSA), t5 (56 HSA) dan t6 (70 HSA). Tahap awal dilakukan proses ekstraksi tanah terkontaminasi minyak bumi dengan menimbang $5 \mathrm{~g}$ sampel tanah dan menambahkan $10 \mathrm{~mL}$ pelarut $\mathrm{n}$-Heksan ke dalam botol vial ukuran $50 \mathrm{~mL}$. Selanjutnya dilakukan pengocokan menggunakan alat pengocok dengan kecepatan 7 rpm selama 30 menit.

Tahap kedua adalah tahap pemisahan, yaitu proses ekstrasksi yang dilakukan tiga kali dengan menggunakan n-heksan ke botol vial ukuran $25 \mathrm{~mL}$ sampai larutan menjadi bening Kemudian dilakukan penimbangan botol vial awal. Pada tahap ini hidrokarbon akan terpisah dan mengendap di dasar botol vial. Tahap ketiga adalah tahap penguapan, TPH dan n-Heksan yang sudah dipisahkan pada tahap pemisahan diuapkan selama 3-5 hari untuk memperoleh residu TPH. Tahap keempat adalah tahap gravimetri, yaitu penimbangan TPH pada botol vial akhir setelah n-heksan menguap total. Kemudian dilakukan perhitungan konsentrasi TPH untuk mengetahui jumlah persentase minyak bumi yang berhasil terdegradasi.

\section{Populasi Azotobacter sp.}

Total Populasi Azotobacter sp. dihitung berdasarkan hasil analisis populasi Azotobacter sp. dengan metode TPC (Total Plate Count), yaitu menghitung isolat mikroba pada tujuh titik pengamatan t0 (0 HSA), t1 (7 HSA), t2 (14 HSA), t3 (28 HSA), t4 (42 HSA), t5 (56 HSA) dan t6 (70 HSA) di media selektif. Analisis TPC Azotobacter sp. dapat dilakukan dengan menimbang $10 \mathrm{~g}$ sampel tanah yang disuspensikan ke dalam $90 \mathrm{~mL}$ larutan garam fisiologis steril, kemudian dilakukan pengenceran serial dengan menggunakan $9 \mathrm{~mL}$ garam fisiologis steril hingga pengenceran 10-7. Sebanyak $1 \mathrm{~mL}$ dari setiap seri pengenceran kemudian diinokulasikan ke dalam medium seleksi Azotobacter sp. (Ashbys padat), yang diinkubasi pada temperatur 30oC. Koloni Azotobacter sp. akan tampak setelah 24 jam inkubasi dengan ciri putih basah berubah menjadi coklat gelap setelah 3-5 hari.

\section{Bobot Kering Tanaman}

Pengukuran bobot kering tanaman dilakukan secara destruktif pada umur 77 HST. Bobot kering tanaman ditimbang setelah tanaman dikeringkan di dalam oven selama 2 × 24 jam hingga mencapai berat konstan.

\section{HASIL DAN PEMBAHASAN}

\section{Populasi Azotobacter sp.}

Azotobacter sp. adalah spesies rhizobakteria yang telah dikenal sebagai agen biologis penambat N2 diazotrof, yang menkonversi dinitrogen ke amonium melalui reduksi elektron dan protonasi gas dinitrogen. Berdasarkan hasil analisis (Tabel 1) diketahui bahwa kombinasi BPN dan pupuk kotoran sapi pada keempat perlakuan memberikan pengaruh yang tidak berbeda nyata terhadap populasi Azotobacter sp. pada 0 Hari Setelah Aplikasi (HSA), namun cenderung meningkat pada perlakuan tanpa BPN + PKS dosis 100\% dengan jumlah populasi Azotobacter sp. sebanyak 0.0120 x $108 \mathrm{CFU} / \mathrm{g}$.

Peningkatan populasi Azotobacter sp. selama proses fitoremediasi tanah tercemar minyak bumi diduga terjadi karena jenis bakteri indigenous yang terdapat pada tanah tercemar minyak bumi mampu beradaptasi dengan baik pada kondisi lingkungan toksik, diduga bakteri tersebut bersifat heterotrofik sehingga lebih toleran pada lingkungan asam, dan tumbuh lebih cepat dengan hasil yang lebih tinggi pada kondisi dengan konsentrasi DO rendah (Zhao et al. 1999).

Populasi Azotobacter sp. terus mengalami peningkatan hingga 70 HSA, dengan perlakuan terbaik terdapat pada kombinasi tanpa BPN + PKS dosis $100 \%$ yang memberikan pengaruh berbeda nyata dibandingkan Azotobacter sp. + tanpa PKS dengan populasi Azotobacter sp. sebanyak 4.8 x $108 \mathrm{CFU} / \mathrm{g}$. 
Peningkatan jumlah sel bakteri yang terjadi merupakan fase log karena bakteri indigenous telah beradaptasi dengan lingkungan toksik sehingga dapat memanfaatkan minyak bumi sebagai sumber karbon utama untuk pertumbuhannya sehingga bakteri dapat melakukan pembelahan sel yang ditunjukkan dengan populasi Azotobacter sp. yang meningkat.

Tabel 1. Pengaruh mandiri penambahan BPN dan pupuk kotoran sapi terhadap populasi Azotobacter sp. pada 0 HSA dan 70 HSA

\begin{tabular}{lcc}
\hline \multicolumn{1}{c}{ Perlakuan } & Populasi Azotobacter sp. (108CFU/g) \\
& 0 HSA & $70 \mathrm{HSA}$ \\
\hline $\mathrm{a}_{0} \mathrm{~b}_{0}=$ control & $0.0071^{\mathrm{a}}$ & $4.5000^{\mathrm{ab}}$ \\
$\mathrm{a}_{2} \mathrm{~b}_{0}=$ Azotobacter sp. + tanpa PKS & $0.0060^{\mathrm{a}}$ & $2.1333^{\mathrm{b}}$ \\
$\mathrm{a}_{0} \mathrm{~b}_{2}=$ tanpa BPN + PKS dosis $100 \%$ & $0.0120^{\mathrm{a}}$ & $4.8000^{\mathrm{a}}$ \\
$\mathrm{a}_{2} \mathrm{~b}_{2}=$ Azotobacter sp. $4 \%+$ PKS dosis $100 \%$ & $0.0064^{\mathrm{a}}$ & $3.7333^{\mathrm{ab}}$ \\
\hline
\end{tabular}

Keterangan : Angka yang diikuti notasi yang sama tidak berbeda nyata menurut uji lanjut (DMRT) Duncan Multiple Range Test pada taraf kepercayaan $95 \%$.

HSA : Hari Setelah Aplikasi

Menurut (Thiel 1999) fase log adalah fase meningkatnya jumlah sel bakteri secara eksponensial karena sel terus membelah dengan laju yang konstan. Pertumbuhan yang lambat pada perlakuan tanpa BPN saat inkubasi 0 HSA diduga karena Azotobacter sp. tidak dapat menggunakan senyawa dalam minyak bumi untuk pertumbuhannya, namun demikian peningkatan jumlah sel bakteri tetap terjadi pada 70 HSA karena diduga hampir sebahagian Azotobacter sp. telah lisis yang isi selnya dapat menjadi nutrisi bagi Azotobacter sp. yang masih hidup. Adanya peningkatan jumlah sel bakteri pada perlakuan tanpa BPN menunjukkan bahwa bakteri indigenous yang terdapat pada penelitian ini merupakan bakteri hidrokarbonoklastik.

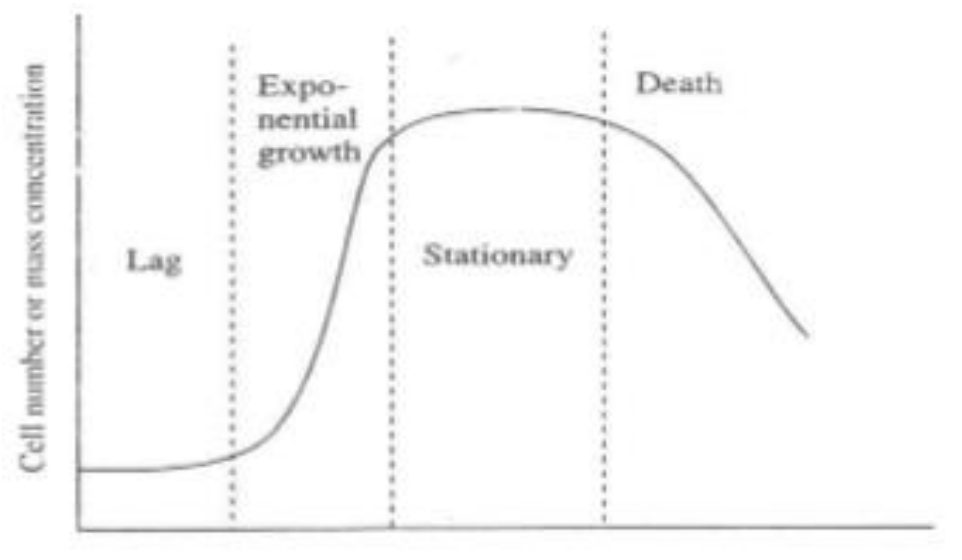

Gambar 1. Grafik Pertumbuhan Bakteri

Penambahan PKS dosis $100 \%$ juga memberikan peranan penting dalam menyediakan $\mathrm{C} / \mathrm{N}$ yang cukup untuk perumbuhan sel Azotobacter sp. sehingga sumber $\mathrm{C}$ sebagai energi dan $\mathrm{N}$ untuk sintesis protein menjadi tersedia. Rasio $\mathrm{C} / \mathrm{N}$ yang terlalu tinggi menyebabkan mikroba kekurangan $\mathrm{N}$ untuk sintesis protein sehingga dekomposisi berjalan lambat (Isroi 2008), sedangkan C/N rendah juga dapat menyebabkan amoniak (NH3) yang dihasilkan oleh bakteri amoniak menjadi terlalu banyak di dalam tanah. Senyawa ini dapat dioksidasi lebih lanjut menjadi nitrit dan nitrat yang mudah diserap oleh tanaman. Perbandingan $\mathrm{C} / \mathrm{N}$ terlalu rendah juga akan membentuk gas amoniak sehingga nitrogen mudah hilang ke udara (Harada et al. 1993).

\section{Laju Degradasi Hidrokarbon}

Laju degradasi hidrokarbon adalah besarnya berat molekul hidrokarbon yang dapat didegradasi oleh mikroba pendegradasi hidrokarbon dalam waktu tertentu. Berdasarkan hasil analisis (Tabel 2), perlakuan bakteri Azotobacter sp. 4\% + tanpa PKS menghasilkan laju degradasi hidrokarbon tertinggi 
dibandingkan dengan perlakuan Azotobacter sp. 4\% + PKS dosis 100\% dengan nilai laju sebesar 0.1047 ppm/hari.

Komponen hidrokarbon minyak bumi yang terdegradasi pada 70 HSA memiliki nilai laju yang lebih kecil dibandingkan tahap awal inkubasi, hal ini diduga karena senyawa hidrokarbon yang terdegradasi masih dalam bentuk senyawa aromatik atau senyawa hasil metabolisme yang bersifat toksik. Menurut (Astuti 2012) tidak semua bakteri mampu menggunakan senyawa aromatik atau senyawa hasil metabolismenya sebagai sumber karbon untuk tumbuh.

Tabel 2. Pengaruh penambahan BPN dan pupuk kotoran sapi terhadap laju degradasi hidrokarbon pada 0-70 HSA

\begin{tabular}{lc}
\hline \multicolumn{1}{c}{ Perlakuan } & Laju Degradasi Hidrokarbon (ppm/hari) \\
& $0-70 \mathrm{HAS}$ \\
\hline $\mathrm{a}_{0} \mathrm{~b}_{0}=$ control & $0.0838^{\mathrm{ab}}$ \\
$\mathrm{a}_{2} \mathrm{~b}_{0}=$ Azotobacter sp. + tanpa PKS & $0.1047^{\mathrm{a}}$ \\
$\mathrm{a}_{0} \mathrm{~b}_{2}=$ tanpa BPN + PKS dosis $100 \%$ & $0.0838^{\mathrm{ab}}$ \\
$\mathrm{a}_{2} \mathrm{~b}_{2}=$ Azotobacter sp. $4 \%+$ PKS dosis $100 \%$ & $0.0628^{\mathrm{b}}$
\end{tabular}

Keterangan : Angka yang diikuti notasi yang sama tidak berbeda nyata menurut uji lanjut (DMRT) Duncan Multiple Range Test pada taraf kepercayaan $95 \%$.

HSA : Hari Setelah Aplikasi

Penurunan hidrokarbon minyak bumi juga dapat disebabkan oleh peran Azotobacter sp. yang memiliki kemampuan untuk menghasilkan biosurfaktan yang berfungsi sebagai pengemulsi limbah minyak bumi sehingga mendukung kinerja mikroorganisme indigenous dalam menyisihkan senyawa hidrokarbon (Suryatmana 2006).

Ketersediaan nutrien yang semakin berkurang sedangkan jumlah sel bakteri yang tinggi akan menyebabkan terjadinya kompetisi. Kompetisi yang semakin besar dalam memanfaatkan nutirien menyebabkan penyerapan hara oleh bakteri semakin terhambat dan tidak optimal. Pertumbuhan bakteri yang terhambat akan menyebabkan proses degradasi hidrokarbon menjadi lambat bahkan cenderung menurun. Menurut (Atlas 1981) semakin banyak sel bakteri akan menyebabkan defisiensi nutrien semakin cepat. Konsentrasi nutrien yang menurun dapat menjadi penghambat mikroorganisme dalam melakukan proses degradasi (Ghazali et al. 2004). Senyawa yang tidak terdegradasi lebih lanjut akan terakumulasi dan menjadi lebih toksik untuk mikroba (Hee et al. 1997).

Adanya persaingan antar mikroba dalam mendapatkan ruang di permukaan akar untuk mendapatkan nutrisi yang dikeluarkan oleh eksudat akar dapat menghambat pertumbuhan mikroba dalam jumlah besar (Prayitno 2017).Selain itu perubahan kondisi kultur yang disebabkan oleh terjadinya transformasi substrat, terkadang juga dapat menyebabkan konsentrasi larutan yang lebih toksik bagi kultur agen hayati sehingga bakteri sulit untuk beradaptasi. Menurut Allen et al. (1998) dalam Suryatmana (2006) tingkat kelarutan minyak bumi adalah salah satu faktor penting yang perlu diperhatikan untuk memenuhi kesiapan substrat agar dapat segera digunakan oleh mikroorganisme tanah.

Penambahan bahan organik penting untuk memperbaiki struktur tanah karena dapat menstimulasi mikroagregasi tanah tercemar melalui interaksi arganomineral (Yuan, 2016). Penambahan PKS dosis $100 \%$ diduga memiliki peran sebagai sumber $\mathrm{C}$ bagi mikroba. Beberapa senyawa organik yang dikeluarkan melalui eksudat akar (misalnya fenolik, asam organik, alkohol, protein) dapat menjadi sumber karbon dan nitrogen sebagai sumber pertumbuhan mikroba yang dapat membantu proses degradasi senyawa organik (Barokah et al. 2011).

Adanya peningkatan degradasi hidrokarbon menunjukkan bahwa bakteri yang digunakan mampu memanfaatkan hidrokarbon yang terdapat pada tanah tercemar minyak bumi sebagai sumber karbon untuk pertumbuhan bakteri yang disertai dengan tingginya laju pertumbuhan bakteri, namun demikian laju degradasi hidrokarbon yang semakin menurun disebabkan karena konsentrasi minyak bumi yang terlalu tinggi maupun toksisitas yang dihasilkan selama proses degradasi serta bentuk atau struktur kimia yang terdapat pada minyak bumi tersebut. 


\section{Bobot Kering Tanaman Rami}

Pengamatan bobot kering tanaman sangat dipengaruhi oleh faktor fisiologi dan lingkungan, sehingga dapat mempengaruhi pertumbuhan vegetatif tanaman. Bobot kering tanaman merupakan parameter yang menggambarkan berlangsungnya pertumbuhan tanaman sebagai hasil dari proses fotosintesis tanaman. Berdasarkan (Tabel 3.) kombinasi BPN dan PKS pada Azotobacter sp. + tanpa PKS memberikan pengaruh yang berbea nyata dibandingkan dengan perlakuan tanpa BPN + PKS dosis $100 \%$ yang memiliki bobot kering tertinggi sebesar $40.433 \mathrm{~g}$. Hal ini diduga karena bakteri indigenous yang terdapat pada tanah tercemar minyak bumi tersebut mampu beradaptasi dengan pada lingkungan yang toksik.

Tabel 3. Pengaruh mandiri penambahan BPN dan pupuk kotoran sapi terhadap bobot kering tanaman

\begin{tabular}{lc}
\hline \multicolumn{1}{c}{ Perlakuan } & Bobot Kering Tanaman $(\mathrm{g})$ \\
& $0-70$ HAS \\
\hline $\mathrm{a}_{0} \mathrm{~b}_{0}=$ control & $28.157^{\mathrm{ab}}$ \\
$\mathrm{a}_{2} \mathrm{~b}_{0}=$ Azotobacter sp. + tanpa PKS & $40.443^{\mathrm{a}}$ \\
$\mathrm{a}_{0} \mathrm{~b}_{2}=$ tanpa BPN + PKS dosis $100 \%$ & $22.543^{\mathrm{b}}$ \\
$\mathrm{a}_{2} \mathrm{~b}_{2}=$ Azotobacter sp. $4 \%+$ PKS dosis $100 \%$ & $33.613^{\mathrm{ab}}$ \\
\hline
\end{tabular}

Keterangan : Angka yang diikuti notasi yang sama tidak berbeda nyata menurut uji lanjut (DMRT) Duncan Multiple Range Test pada taraf kepercayaan $95 \%$.

Azotobacter sp. dapat berperan dalam peningkatan kadar air tanaman melalui peningkatan perakaran yang difasilitasi oleh fitohormon dan eksopolisakarida yang dihasilkannya (Patel 2010), sedangkan penambahan bahan organik pada dosis tertentu dapat menyebabkan tanaman tidak dapat menjaga kadar airnya sehingga dapat menurunkan berat kering tanaman (Hindersah 2018). Penambahan pupuk kotoran sapi juga dapat meningkatkan pertumbuhan tanaman dikarenakan sifatnya yang dapat memperbaiki struktur tanah, meningkatkan daya serap terhadap air, dan juga dapat meningkatkan kandungan unsur hara makro dan mikro (Samekto 2006). Perakaran yang lebih masif dapat meningkatkan serapan air dan nutrisi (Mursito \& Kawiji 2002).

\section{SIMPULAN}

Kombinasi tebaik terdapat pada perlakuan tanpa BPN + PKS dosis 100\% yang dapat meningkatkan populasi Azotobacter sp. sebesar 4,8 x $108 \mathrm{CFU/g}$, serta penambahan Azotobacter sp. + tanpa PKS mampu meningkatkan laju degradasi hidrokarbon dan bobot kering tanaman masing-masing sebesar $0,1047 \mathrm{ppm} / \mathrm{hari}$ dan $40,433 \mathrm{~g}$.

\section{DAFTAR PUSTAKA}

Alexander M. 1977. Soil Microbiology. 2Nd edition. New York: John Wiley and Sons, Inc.

Allen CCR, DR Boyd, F Hempenstall, MJ Franklin, ND Sarma. 1998. Contrasting effect of a nonionic surfactant on the biotransformation of polysiclic aromatic hydrocarbon to cis-dihydrodiols by soil bacterial. Appl. Environ. Microbiol. 65 : 1335-1339.

Astuti D. 2012. Pengaruh variasi jumlah inokuum konsorsium bakteri terhadap degradasi hidrokarbon minyak bumi. Skripsi. FMIPA Universitas Indonesia, Depok.

Atlas RM. 1981. Microbial degradation of petroleum hydrocarbons: an environmental perspective. Microbiol. Rev. 45(1): 180-209.

Barokah A, LO Sumarlin, AS Mujab. 2011. Penggunaan biokompos dalam bioremediasi lahan termar libah minyak bumi. Valensi. 2(3) : 430-443.

Fauzi M. 2017. Peran bioagen pada proses fitoremediasi minyak bumi menggunakan tanaman rami (Boehmeria nivea. L). Universitas Padjadjaran, Sumedang.

Ghazali FM, RNZA Rahman, AB Salleh, M Basri. 2004. Biodegradation of hydrocarbons in soil by microbial consortium. Int. Biodeter. Biodegr. 54: 61-67.

Harada YK, T Haga, M Osada, M Kashinoa. 1993. Quality of Compost from Animal Waste. JAQR 26 (4):238246.

Hee SB, JM Lee, ST Lee. 1997. Biodegradation of the mixture of 2,4,6- trichlorophenol, 4-chlorophenol, and phenol by a defined mixed culture. J. Gen. Appl. Microbiol. 4:97-103

Hindersah R, M Kalay, A Talahaturuson. 2018. Bakteri Pemfiksasi Nitrogen Azotobacter sebagai pupuk hayati dan pengendalian penyakit pada tanaman kacang panjang. AGRIC. 30(1): 25-32. 
Isroi. 2008. Kompos. Balai Penelitian Bioteknologi Perkebunan Indonesia, Bogor.

[KESDM] Kementerian Energi dan Sumber Daya Mineral. 2016. Trend produksi minyabumiIndonesia.Online:http://migas.esdm.go.id/post/read/produksi-minyak-bumi-terus-meningkat.

Kepmen LH No. 128 Tahun 2003 Tata Cara dan Persyaratan Teknis Pengolahan Tanah Terkontaminasi Minyak Bumi secara Biologis.

Mursito D,Kawiji. 2002. Pengaruh kerapatan tanam dan kedalaman olah tanah terhadap hasil umbi lobak (Raphanus sativus L.). Agrosains. 4: 1-6

Patel MJ, NM Patel, RB Patel, RP Patel. 2010, Formulation and Evaluation of Self-Microemulsifying Drug Delivery System of Lovastatin. Asian. J. Pharm. Sci. 5(6): 266-267.

Pratiwi GA, D Herdiyantoro, P Suryatmana. 2017. Pengaruh pupuk hayati dan dosis Azotobacter sp. dalam fitoremediasi menggunakan tanaman rami (Boehmeria nivea L.) pada tanah tercemar hidrokarbon minyak bumi. Universitas Padjadjaran, Sumedang.

Prayitno J. 2017. Ujicoba konsorsium mikroba dalam upaya bioremediasi tanah tercemar minyak dengan menggunakan teknik landfarming skala bangku. Badan Pengkajian dan Penerapan Teknologi, Tangerang Selatan.

Samekto R. 2006. Pupuk Kompos. Yogyakarta: PT Citra Aji Parama.

Sugito Y, Y Nuraini, E Nihayati. 1995. Sistem pertanian organik. Fakultas Pertanian, Universitas Brawijaya. Malang.

Suryatmana P. 2006. Biodegradasi hidrokarbon minyak bumi dengan penambahan Azotobacter chroococcum AC04 sebagai bakteri penghasil biosurfaktan. Institute Teknologi Bandung, Bandung.

Thiel T. 1999. Introduction to bacteria. Departement of Biology. University of Missouri St. Louis, $9 \mathrm{hlm}$.

[USEPA] United States Environmental Protection Agency. 2002. Introduction to Phytoremediation. EPA 600/R99/107, U.S.

Walhi. 2007. Kompleksitaspersoalansampah.Online:http://www.walhi.or.id/kampanye/cemar/sampah/070528_ smph_cu

Wei SH, QX Zhou. 2006. Phytoremdiation of cadmium-contaminated soils by Rorippa globosa using two-phase planting. Environ. Sci. Pollut. Res. 13: 151-155.

Widyati E. 2009. Kajian fitoremediasi sebagai salah satu upaya menurunkan akumulasi logam akibat air asam tambang pada lahan bekas tambang batu bara. J. Pusat Litbang Hutan dan Konservasi Alam. Tekno Hutan Tanaman 2(2): 67-75.

Yuan M, ZP Xu, T Baumgartil, L Huang. 2016. Organic mendment and plant growth improved aggregation in $\mathrm{Cu} / \mathrm{Pb}-\mathrm{Zn}$ Tailing. Soil. Sc. Soc. Am. J. 80(1): 27-37.

Zhao HW, DS Mavinic, WK Oldham, FA Koch. 1999. Controlling factors for simultaneous nitrification and denitrifycation in a two-stage intermittent aeration process treating domestic sewage. Water Resour. 33(4):961970. 